\title{
New Staphylinidae (Coleoptera) records with new collection data from New Brunswick, Canada: Paederinae
}

\author{
Reginald P. Webster', Ian DeMerchant' \\ I Natural Resources Canada, Canadian Forest Service - Atlantic Forestry Centre, 1350 Regent St., P.O. Box \\ 4000, Fredericton, NB, Canada E3B 5P7 \\ Corresponding author: Reginald P. Webster (reginaldwebster@rogers.com) \\ Academic editor:J. Klimaszewski | Received 6 December 2011 | Accepted 26 January 2012 | Published 26 April 2012 \\ Citation: Webster RP, DeMerchant I (2012) New Staphylinidae (Coleoptera) records with new collection data from \\ New Brunswick, Canada: Paederinae. In: Klimaszewski J, Anderson R (Eds) Biosystematics and Ecology of Canadian \\ Staphylinidae (Coleoptera) II. ZooKeys 186: 273-292. doi: 10.3897/zookeys.186.2504
}

\begin{abstract}
We report 17 species of Paederinae new for New Brunswick, Canada. Ten of these species, Lathrobium othioides LeConte, Lathrobium amplipenne Casey, Lathrobium armatum Say, Lathrobium confusum LeConte, Lathrobium debile LeConte, Achenomorphus corticinus (Gravenhorst), Rugilus rufipes Germar, Homaeotarsus bicolor (Gravenhorst), Homaeotharsus cribratus (LeConte), and Homaeotarsus pallipes (Gravenhorst) are newly recorded for the Maritime provinces. This brings the total number of Paederinae recorded from New Brunswick to 36 species. Additional records are presented for the recently reported Lathrobium simile LeConte and Lathrobium washingtoni Casey. Collection and habitat data are presented for all species.
\end{abstract}

\section{Keywords}

Paederinae, new records, Canada, New Brunswick

\section{Introduction}

This paper treats new Staphylinidae records from New Brunswick of the subfamily Paederinae. The most recent taxonomic treatments of the North American Paederinae fauna were by Casey $(1905,1910)$. More recently Watrous (1981) reviewed the Tetartopeus (as a subgenus of Lathrobium) and the subgenus Eulathrobium of Lobrathium. Herman (1965a, b) revised the genus Orus. Many other genera in North America are in need of a modern revision.

Copyright Her Majesty the Queen in Right of Canada. This is an open access article distributed under the terms of the Creative Commons Attribution License 3.0 (CC-BY), which permits unrestricted use, distribution, and reproduction in any medium, provided the original author and source are credited. 
Many species of Paederinae in Canada occur in and near wetland habitats such as marshes, bogs, and pond and river margins (Watrous 1980, 1981; Newton et al. 2000; Brunke et al. 2011). A few species, such as Sunius confluentus (Say), occur in subcortical habitats (Brunke et al. 2011). However, relatively little has been published on the bionomics of species occurring in Canada or North America.

Campbell and Davies (1991) reported 15 species of Paederinae from New Brunswick. Klimaszewski et al. (2005) added Lathrobium simile LeConte, Lathrobium. washingtoni Casey, and Ochthephilum fracticorne (Paykull) from their study on rove beetles in red spruce (Picea rubens Sarg.) stands. The adventive Lathrobium fulvipenne (Gravenhorst) was reported from New Brunswick by Majka and Klimaszewski (2008). Here, we report an additional 17 species of Paederinae for New Brunswick, bringing the total number of species known from the province to 36 .

\section{Methods and conventions}

The following records are based on specimens collected as part of a general survey to document the Coleoptera fauna of New Brunswick and from by-catch samples from Lindgren 12-funnel traps (Lindgren 1983) obtained during a study to develop a general attractant for the detection of invasive species of Cerambycidae.

\section{Collection methods}

Various collection methods were employed to collect the species reported in this study. Details are outlined in Campbell (1973) and Webster et al. (2009, Appendix). See Webster et al. (2012) for details of the methods used for deployment of Lindgren traps and sample collection. A description of the habitat was recorded for all specimens collected during this survey. Locality and habitat data are presented exactly as recorded on labels for each specimen. This information, as well as additional collecting notes, is summarized and discussed in the collection and habitat data section for each species.

\section{Specimen preparation}

Males and some females of most species were dissected to confirm their identity. The genital structures were dehydrated in absolute alcohol, mounted in Canada balsam on celluloid microslides, and pinned with the specimens from which they originated.

\section{Distribution}

Distribution maps, created using ArcMap and ArcGIS, are presented for each species in New Brunswick. Every species is cited with current distribution in Canada and Alaska, using abbreviations for the state, provinces, and territories. New provincial 
records are indicated in bold under Distribution in Canada and Alaska. The following abbreviations are used in the text.

\begin{tabular}{ll|ll}
\hline AK & Alaska & MB & Manitoba \\
\hline YT & Yukon Territory & ON & Ontario \\
\hline NT & Northwest Territories & QC & Quebec \\
\hline NU & Nunavut & NB & New Brunswick \\
\hline BC & British Columbia & PE & Prince Edward Island \\
\hline AB & Alberta & NS & Nova Scotia \\
\hline SK & Saskatchewan & NF \& LB & Newfoundland and Labrador* \\
\hline
\end{tabular}

*Newfoundland and Labrador are each treated separately under the current Distribution in Canada and Alaska.

Acronyms of collections examined and referred to in this study are as follows:

AFC Atlantic Forestry Centre, Natural Resources Canada, Canadian Forest Service, Fredericton, New Brunswick, Canada

CNC Canadian National Collection of Insects, Arachnids and Nematodes, Agriculture and Agri-Food Canada, Ottawa, Ontario, Canada

NBM New Brunswick Museum, Saint John, New Brunswick, Canada

RWC Reginald P. Webster Collection, Charters Settlement, New Brunswick, Canada

\section{Results}

Unless noted otherwise (additional records), all records below are species newly recorded for New Brunswick, Canada. Species followed by ${ }^{* *}$ are newly recorded from the Maritime provinces (New Brunswick, Nova Scotia, Prince Edward Island) of Canada.

\section{Species accounts}

The classification of the Paederinae follows Bouchard et al. (2011).

Seventeen species of Paederinae are newly reported for the New Brunswick, Canada. Ten of these are newly recorded for the Maritime provinces. This brings the total number of Paederinae recorded from New Brunswick to 36 (Table 1). Additional records and bionomic data of the recently reported Lathrobium simile and L. washingtoni are presented.

Table I. Species of Paederinae (Staphylinidae) recorded from New Brunswick, Canada.

\begin{tabular}{l}
$\frac{\text { Subfamily Paederinae Fleming }}{\text { Tribe Paederini Fleming }}$ \\
\hline Subtribe Lathrobiina Laporte \\
Lathrobium (Lathrobioma) scolopaceum (Casey) \\
\hline
\end{tabular}

\begin{tabular}{c}
\hline Lathrobium (Lathrobioma) othioides LeConte ${ }^{* *}$ \\
\hline Lathrobium (Lathrobium) amplipenne Casey ${ }^{* *}$ \\
\hline Lathrobium (Lathrobium) armatum Say ${ }^{* *}$ \\
\hline Lathrobium (Lathrobium) confusum LeConte**
\end{tabular}




\begin{tabular}{l}
\hline Lathrobium (Lathrobium) fauveli Duvivier \\
\hline $\begin{array}{l}\text { Lathrobium (Lathrobium) fulvipenne } \\
\text { (Gravenhorst) }\end{array}$ \\
\hline Lathrobium (Lathrobium) simile LeConte \\
\hline Lathrobium (Lathrobium) sparsellum Casey \\
\hline Lathrobium (Lathrobium) spissicorne Casey* \\
\hline Lathrobium (Lathrobium) washingtoni Casey \\
\hline Lathrobium (Lathrolepta) debile LeConte** \\
\hline Lobrathium (Lobrathium) collare (Erichson)* \\
\hline Lobrathium (Eulathrobium) grande (LeConte) \\
\hline Tetartopeus angularis (LeConte) \\
\hline Tetartopeus furvulus Casey \\
\hline Tetartopeus lacustris Casey \\
\hline Tetartopeus niger (LeConte) \\
\hline Tetartopeus nitidulus (LeConte) \\
\hline Tetartopeus capitosus Casey* \\
\hline Tetartopeus rubripennis Casey* \\
\hline Subtribe Medonina Casey \\
\hline Achenomorphus corticinus (Gravenhorst)** \\
\hline Lithocaris (Lithocharis) ochracea (Gravenhorst)
\end{tabular}

\begin{tabular}{c}
\hline Pseudomedon thoracica Casey \\
\hline Sunius (Trachysectus) confluentus (Say) \\
\hline Subtribe Stilicina Casey \\
\hline Pachystilicus hanhami (Wickham) \\
\hline Rugilus angustatus (Geoffrey)* \\
\hline Rugilus biarmatus (LeConte) \\
\hline Rugilus rufipes Germar** \\
\hline Subtribe Astenina Hatch \\
\hline Astenus discopunctatus (Say) \\
\hline Subtribe Cryptobiina Casey \\
\hline $\begin{array}{l}\text { Homaeotarsus (Gastrolobium) bicolor } \\
\text { (Gravenhorst)** }\end{array}$ \\
\hline Homaeotarsus (Hesperobium) cinctus (Say)* \\
\hline $\begin{array}{l}\text { Homaeotarsus (Hesperobium) cribratus } \\
\text { (LeConte)** }\end{array}$ \\
\hline $\begin{array}{l}\text { Homaeotarsus (Hesperobium) pallipes } \\
\text { (Gravenhorst) }\end{array}$ \\
\hline Ochthephilum fracticorne (Paykull) \\
\hline Subtribe Paederina Fleming \\
\hline Paederus littorarius (Gravenhorst)
\end{tabular}

Notes: ${ }^{*}$ New to province, ${ }^{* *}$ New to Maritime Provinces

Family Staphylinidae Latreille, 1802

Subfamily Paederinae Fleming, 1821

Tribe Paederini Fleming, 1821

\section{Subtribe Lathrobiina Laporte, 1835}

\section{Lathrobium (Lathrobioma) othioides LeConte, 1880**}

http://species-id.net/wiki/Lathrobium_othioides

Map 1

Material examined. New Brunswick, Carleton Co., Richmond, Hovey Hill Protected (Natural) Area, $46.1115^{\circ} \mathrm{N}, 67.7770^{\circ} \mathrm{W}, 10 . \mathrm{V} .2005$, R. P. Webster, hardwood forest, in moist leaf litter and moss near seepage area ( $3 \hat{\delta}$, RWC). Sunbury Co., Acadia Research Forest, $45.9816^{\circ} \mathrm{N}, 66.3374^{\circ} \mathrm{W}, 18 . \mathrm{VI} .2007$, R. P. Webster, 8.5 yearold regenerating mixed forest, sifting leaf litter ( $1 \hat{\delta}$, AFC). York Co., Charters Settlement, $45.8428^{\circ} \mathrm{N}, 66.7279^{\circ} \mathrm{W}, 19 . \mathrm{IV} .2004$, 24.IV.2004, 15.IV.2005, 20.IV.2005, R. P. Webster, mixed forest, sedge marsh in moist grass litter and sphagnum $(6 \hat{\jmath}, \mathrm{RWC})$.

Collection and habitat data. Lathrobium othioides was found in an old hardwood forest, a regenerating mixed forest, and a sedge (Carex) marsh. Adults were sifted from leaf litter, moist leaf litter, and moss in a seepage area and from moist grass litter and sphagnum. This species was collected during April, May, and June.

Distribution in Canada and Alaska. ON, QC, NB (Campbell and Davies 1991). 
Lathrobium (Lathrobium) amplipenne Casey, 1905**

http://species-id.net/wiki/Lathrobium_amplipenne

Map 2

Material examined. New Brunswick, Restigouche Co., Little Tobique River near Red Brook, $47.4465^{\circ} \mathrm{N}, 67.0689^{\circ} \mathrm{W}, 13 . \mathrm{VI} .2006$, R. P. Webster, river margin in Carex hummock (1 $\hat{0}, 1$ q, RWC). Sunbury Co., Sheffield, Portobello Creek N.W.A., $45.8952^{\circ} \mathrm{N}, 66.2728^{\circ} \mathrm{W}, 7 . V .2004$, R. P. Webster, silver maple swamp, in leaf litter (1 ․, RWC).

Collection and habitat data. Adults were sifted from a Carex hummock on a river margin and from leaf litter in a silver maple (Acer saccharinum L.) swamp. Adults were collected during May and June.

Distribution in Canada and Alaska. ON, NB (Campbell and Davies 1991).

\section{Lathrobium (Lathrobium) armatum Say, 1834**}

http://species-id.net/wiki/Lathrobium_armatum

Map 3

Material examined. New Brunswick, Carleton Co. Jackson Falls, Bell Forest, $46.2150^{\circ} \mathrm{N}, 67.7201^{\circ} \mathrm{W}, 14 . \mathrm{V} .2006$, R. P. Webster, river margin, in drift material near

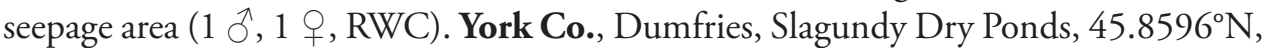
$67.1849^{\circ} \mathrm{W}, 8$.VII.2006, R. P. Webster, large vernal pond, pond margin in moist leaves (1 $\partial^{\lambda}, 2$ ㅇ, RWC); $8.5 \mathrm{~km} \mathrm{~W}$ of Tracy off Rt. $645,45.6888^{\circ} \mathrm{N}, 66.8004^{\circ} \mathrm{W}, 22 . \mathrm{V} .2008$, R. P. Webster, Carex marsh/flowage near slow flowing brook, in Carex hummocks (3 o, 1 ㅇ, RWC).

Collection and habitat data. Lathrobium armatum was sifted from drift material near a seepage area along a river margin, from Carex hummocks in a Carex marsh/flowage near a slow-flowing brook and from moist leaves on the margin of a large vernal pond. Adults were collected during May and July.

Distribution in Canada and Alaska. ON, QC, NB (Campbell and Davies 1991).

Lathrobium (Lathrobium) confusum LeConte, 1880**

http://species-id.net/wiki/Lathrobium_confusum

Map 4

Material examined. New Brunswick, Carleton Co., near Hovey Hill P.N.A., $46.1155^{\circ} \mathrm{N}, 67.7631^{\circ} \mathrm{W}, 10 . \mathrm{V} .2005$, R. P. Webster, mixed forest, in (leaf) litter near small brook ( $1 \mathrm{O}$, RWC); Meduxnekeag Valley Nature Preserve, $46.1964^{\circ} \mathrm{N}$, $67.6840^{\circ} \mathrm{W}, 31$. V.2005, M.-A. Giguère \& R. Webster, mixed forest, vernal pond margin in moist (leaf) litter ( 2 , NBM, RWC); same locality and forest type but, $46.1976^{\circ} \mathrm{N}, 67.6850^{\circ} \mathrm{W}$, margin of vernal pond, in moist leaves $\left(1 \mathrm{O}^{\top}, \mathrm{NBM}\right)$. Queens 
Co., W of Jemseg at "Trout Creek", 45.8227N, 66.1240W, 26.IV.2004, 9.V.2004, R. P. Webster, silver maple swamp, sifting (leaf) litter at bases of large trees (2 $\mathrm{O}^{\top}$, 1 P, RWC); same locality, forest type, and collector but $45.8231^{\circ} \mathrm{N}, 66.1245^{\circ} \mathrm{W}$, 11.IV.2006, sifting litter from crotch of silver maple with multiple trunks ( $\left.1 \delta^{\lambda}, \mathrm{NBM}\right)$. Sunbury Co., Sheffield, Portobello Creek N.W.A., $45.8952^{\circ}$ N, 66.2728 ${ }^{\circ}$ W, 7.V.2004, R. P. Webster, silver maple swamp, in leaf litter (1 +, RWC); Burton, Sunpoke Lake, $45.7575^{\circ} \mathrm{N}, 66.5736^{\circ} \mathrm{W}, 30 . I V .2004,10 . I V .2006$, R. P. Webster, red maple swamp, in leaf litter near slow stream (1 O, 3 9 , NBM, RWC). York Co. Kelly’s Creek at Sears Rd., $45.8723^{\circ} \mathrm{N}, 66.8414^{\circ} \mathrm{W}, 7 . V I .2008$, R.P. Webster, alder swamp with red maples, in moist leaf and grass litter near (small) pool (1 $\widehat{\jmath}$, RWC).

Collection and habitat data. Watrous (1980) reported L. confusum from the margin of an intermittent stream. In New Brunswick, adults were found in leaf litter or grass litter near small brooks and streams and in leaf litter along vernal pond and forest pool margins. Some were sifted from leaf litter at the base of large silver maples or from litter in the crotch of a silver maple with multiple trunks. Adults were found in mixed forests, silver maple swamps, red maple (Acer rubrum L.) swamps, and an alder (Alnus sp.) swamp with red maple. This species was collected during April, May, and June.

Distribution in Canada and Alaska. ON, QC, NB (Campbell and Davies 1991).

\section{Lathrobium (Lathrobium) simile LeConte, 1863}

http://species-id.net/wiki/Lathrobium_simile

Map 5

Material examined. Additional New Brunswick records, Carleton Co., Hovey Hill P.N.A., $46.1115^{\circ} \mathrm{N}, 67.7770^{\circ} \mathrm{W}, 10 . V .2005$, R. P. Webster, hardwood forest, in moist leaf litter and moss near forest pool ( $1 \hat{\delta}$, RWC); Meduxnekeag Valley Nature Preserve, $46.1956^{\circ} \mathrm{N}, 67.6803^{\circ} \mathrm{W}, 15 . \mathrm{IX} .2004$, R. P. Webster, mixed forest, in decaying

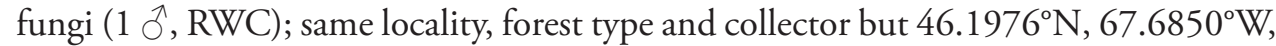
4.V.2006, R. P. Webster, margin of vernal pond, in moist leaf litter (1 $\left.\sigma^{\lambda}, \mathrm{RWC}\right)$; Jackson Falls, Bell Forest, $46.2210^{\circ} \mathrm{N}, 67.7210^{\circ} \mathrm{W}, 11$. V.2005, M.-A. Giguère \& R. Webster, hardwood forest, in leaf litter near small brook (1 $\delta^{\lambda}, 2$, RWC). Sunbury Co., Acadia Research Forest, 30.VI.1999, G. Gesner, Strip Cut 8, Site 1, pitfall trap (1, AFC); Acadia Research Forest, $45.9799^{\circ} \mathrm{N}, 66.3394^{\circ} \mathrm{W}, 18$. VI.2007, R. P. Webster, mature red spruce and red maple forest, sifting leaf litter $(1 \hat{O}, 1$, $\mathrm{RWC})$.

Collection and habitat data. Adults of this species were found in hardwood forests, mixed forests, and a mature red spruce forest. Adults were collected from moist leaf litter near forest pools or vernal ponds, near a small brook, and from the forest floor. One individual was collected from decaying fungi on the forest floor. This species was collected during May, June, and September.

Distribution in Canada and Alaska. MB, ON, QC, NB, NS (Campbell and Davies 1991; Klimaszewski et al. 2005). This species was first reported from New Brunswick by Klimaszewski et al. (2005) from the Acadia Research Forest. 
Lathrobium (Lathrobium) spissicorne Casey, 1905

http://species-id.net/wiki/Lathrobium_spissicorne

Map 6

Material examined. New Brunswick, Charlotte Co., near New River, $45.2118^{\circ} \mathrm{N}$, $66.6179^{\circ} \mathrm{W}, 7 . \mathrm{VII} .2006$, R. P. Webster, mixed forest, margin small pond, treading Carex hummock into water (1 $q$, RWC). Queens Co., W of Jemseg at "Trout Creek", $45.8240^{\circ} \mathrm{N}, 66.1220^{\circ} \mathrm{W}, 4$. VI.2004, R. P. Webster, silver maple swamp, margin of vernal pond in moist leaf litter on muddy soil ( 1 +, $\mathrm{RWC})$; Grand Lake near Scotchtown, $45.8762^{\circ} \mathrm{N}, 66.1816^{\circ} \mathrm{W}, 5 . V I .2004,1 . V I I .2004,25 . V .2006$, R. P. Webster, lakeshore, old (sand) dune with oaks, under dead fish and under drift material (3 ${ }^{\top}, 1$ q, NBM, RWC). Sunbury Co., Burton, Sunpoke Lake, $45.7665^{\circ}$ N, $66.5545^{\circ} \mathrm{W}, 15 . V .2004$, R. P. Webster, (red) oak and (red and silver) maple forest, in leaf litter (3 $\lambda$, RWC).

Collection and habitat data. Lathrobium spissicorne was found in mixed forests, a silver maple swamp, along a lakeshore, and in a mature forest with red oak (Quercus rubra L.), red maple, and silver maple. Adults were found in a Carex hummock on a pond margin, in moist leaf litter on vernal pond margin, and in leaf litter on the forest floor. Some adults were found under drift material and under a dead fish on a lakeshore. This species was collected during May, June, and July.

Distribution in Canada and Alaska. ON, QC, NB, PE (Campbell and Davies 1991).

\section{Lathrobium (Lathrobium) washingtoni Casey, 1905}

http://species-id.net/wiki/Lathrobium_washingtoni

Map 7

Material examined. Additional New Brunswick records, Queens Co., W of Jemseg at "Trout Creek", $45.8227^{\circ} \mathrm{N}, 66.1240^{\circ} \mathrm{W}, 4 . V I .2004$, R. P. Webster, silver maple swamp, sifting litter at base of large tree (silver maple) ( $1 \hat{\jmath}$, RWC). Saint John Co., ca. $2 \mathrm{~km} \mathrm{NE}$ of Maces Bay, 45.1168N, 66.4552 ${ }^{\circ} \mathrm{W}$, 8.V.2006, R. P. Webster, eastern white cedar swamp, in sphagnum and leaf litter $(1+$, RWC). Sunbury Co., Burton, SW of Sunpoke Lake, 45.7575N, 66.5726 W, 17.IV.2005, R. P. Webster, red maple swamp, in leaf litter near margin of slow stream ( 10 , RWC); Acadia Research Forest, $45.9799^{\circ} \mathrm{N}, 66.3394^{\circ} \mathrm{W}, 14 . \mathrm{V} .2007, \mathrm{R}$. P. Webster, mature red spruce and red ma-

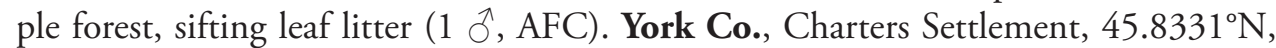
$66.7410^{\circ} \mathrm{W}, 16 . \mathrm{IV} .2004, \mathrm{R}$. P. Webster, mature red spruce and eastern white cedar forest, in moss and litter near small brook (1 $\left.0^{\lambda}, \mathrm{RWC}\right)$; same locality, forest type, and collector but $45.8341^{\circ} \mathrm{N}, 66.7445^{\circ} \mathrm{W}, 27 . I V .2005$, margin of vernal pond in leaf litter ( 1 on, NBM); New Maryland, off Hwy 2, E of Baker Brook, $45.8760^{\circ} \mathrm{N}, 66.6252^{\circ} \mathrm{W}$, 6.IV.2005, 26.IV.2005, 4.VI.2005, R. P. Webster, old growth eastern white cedar swamp, in moss and litter at base of cedar ( $3 \hat{\jmath}, \mathrm{NBM}, \mathrm{RWC})$; Canterbury, Browns Mountain Fen, $45.8967^{\circ} \mathrm{N}, 67.6343^{\circ} \mathrm{W}, 1 . \mathrm{VI} .2005$, M.-A. Giguère and R. Webster, 


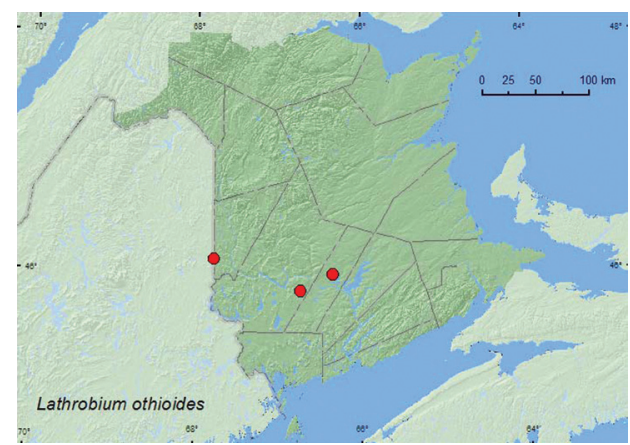

Map I. Collection localities in New Brunswick, Canada of Lathrobium othioides.

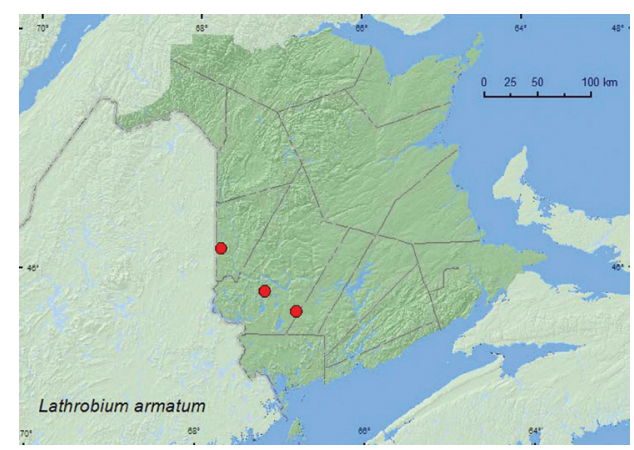

Map 3. Collection localities in New Brunswick, Canada of Lathrobium armatum.

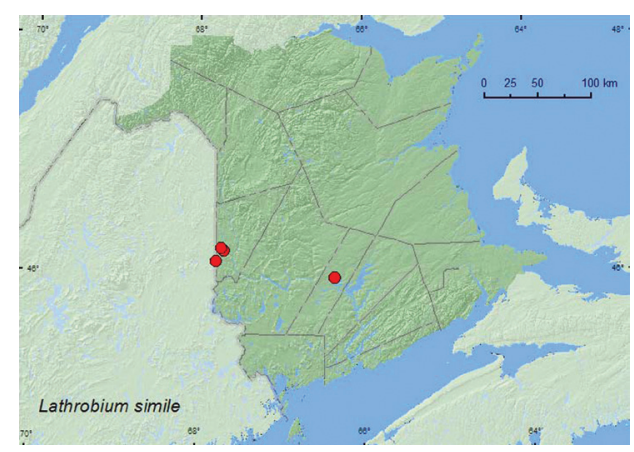

Map 5. Collection localities in New Brunswick, Canada of Lathrobium simile.

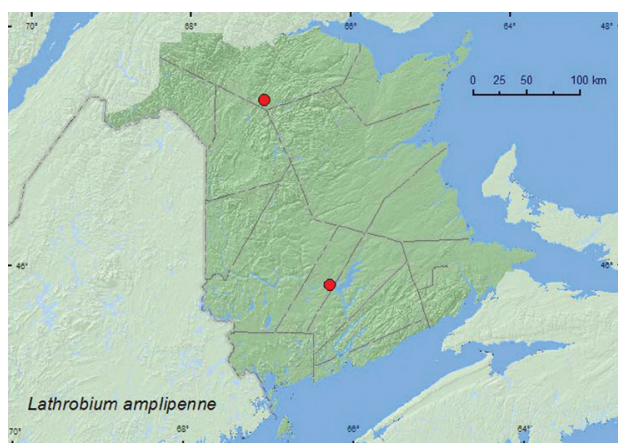

Map 2. Collection localities in New Brunswick, Canada of Lathrobium amplipenne.

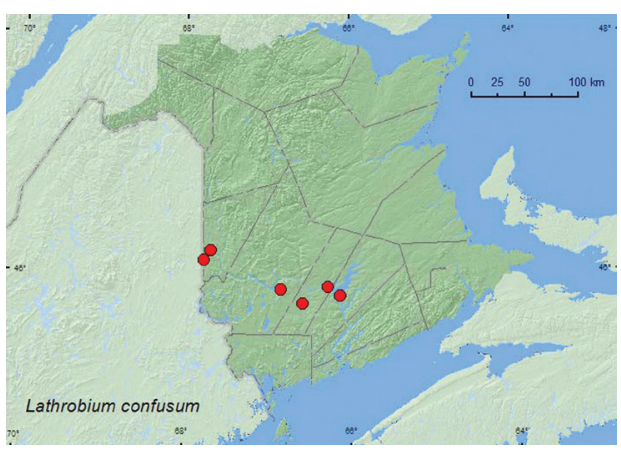

Map 4. Collection localities in New Brunswick, Canada of Lathrobium confusum.

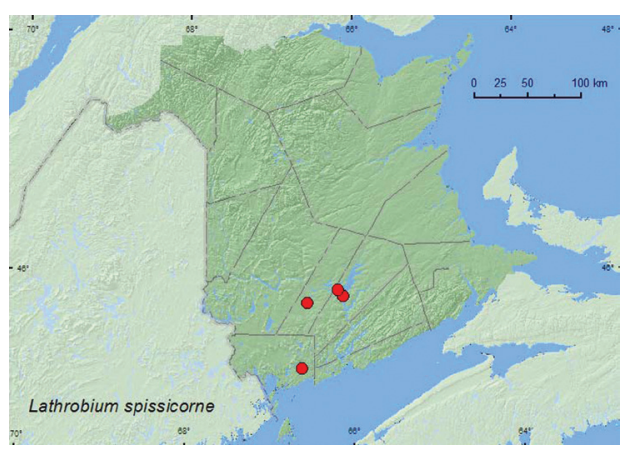

Map 6. Collection localities in New Brunswick, Canada of Lathrobium spissicorne.

calcareous fen, in moist sphagnum ( $\left.1 \mathrm{O}^{\mathrm{N}} \mathrm{NBM}\right)$; Mazerolle Settlement, $45.8729^{\circ} \mathrm{N}$, $66.8311^{\circ} \mathrm{W}, 28 . I V .2006$, R. P. Webster, eastern white cedar swamp, margin of vernal pool in leaf litter ( $1 \hat{\delta}, 1$ q, RWC).

Collection and habitat data. Lathrobium washingtoni was found in eastern white cedar (Thuja occidentalis L.) swamps, a silver maple swamp, a red maple swamp, a 
mature red spruce forest, and in an open calcareous cedar fen. Adults were sifted from sphagnum, sphagnum and leaf litter, moss and/or litter at bases of trees (silver maple, eastern white cedar), leaf litter near the margin of a slow stream and a brook, and from leaf litter on vernal pond margins. Adults were collected during April, May, and June.

Distribution in Canada and Alaska. AK, NT, BC, AB, SK, MB, ON, QC, NB, NS, NF (Campbell and Davies 1991; Klimaszewski et al. 2005). This species was first reported from New Brunswick by Klimaszewski et al. (2005) from the Acadia Research Forest.

\section{Lathrobium (Lathrolepta) debile LeConte, 1880**}

http://species-id.net/wiki/Lathrobium_debile

Map 8

Material examined. New Brunswick, Charlotte Co., at New River, $45.2166^{\circ} \mathrm{N}$, $66.5953^{\circ} \mathrm{W}, 2 . V I .2006$, R. P. Webster, river margin, under debris (1 $\left.\sigma^{\top}, \mathrm{RWC}\right)$. Queens Co., W of Jemseg at "Trout Creek", 45.8227 N, 66.1240W, 4.VI.2004, 3.IV.2006, 11.IV.2006, R. P. Webster, silver maple swamp, sifting litter at base of large tree (silver maple) (2 ô, 1 +, NBM, RWC); Grand Lake near Scotchtown, $45.8762^{\circ} \mathrm{N}$, $66.1816^{\circ} \mathrm{W}, 25 . \mathrm{IV} .2004,12 . V .2004$, R. P. Webster, (red) oak and (silver) maple forest, in leaf litter (2 J, 2 , RWC). Sunbury Co., Burton, SW of Sunpoke Lake, 45.7575N, 66.5726 ${ }^{\circ} \mathrm{W}, 17 . I V .2005$, R. P. Webster, red maple swamp, in leaf litter near margin of slow stream (1 $9, \mathrm{NBM})$. York Co., Charters Settlement, $45.8380^{\circ} \mathrm{N}$, $66.7310^{\circ} \mathrm{W}, 18 . \mathrm{IV} .2004, \mathrm{R}$. P. Webster, mixed forest, in leaf litter near stream (1 9 , RWC); $8.5 \mathrm{~km} \mathrm{~W}$ of Tracy off Rt. $645,45.6821^{\circ} \mathrm{N}, 66.7894^{\circ} \mathrm{W}, 6 . \mathrm{V} .2008$, R. P. Webster, alder swamp, in leaf litter and grass on hummocks (1, RWC); Fredericton, Odell Park, 45.9570 $\mathrm{N}, 66.6695^{\circ} \mathrm{W}, 19 . \mathrm{VI} .2005$, R. P. Webster, old growth hemlock forest, in leaf litter ( $1 \hat{\jmath}$, RWC).

Collection and habitat data. In New Brunswick, L. debile was found in a silver maple swamp, a red oak and silver maple forest, a red maple swamp, a mixed forest, an alder swamp, an old-growth eastern hemlock (Tsuga canadensis (L.) Carr.) forest, and along a river margin. Most adults were sifted from leaf litter on the forest floor or near stream margins. One individual was found under drift material on a river margin. Adults were collected during April, May, and June.

Distribution in Canada and Alaska. ON, QC, NB (Campbell and Davies 1991).

Tetartopeus capitosus Casey, 1905

http://species-id.net/wiki/Tetartopeus_capitosus

Map 9

Material examined. New Brunswick, Queens Co., W of Jemseg at "Trout Creek", $45.8240^{\circ} \mathrm{N}, 66.1220^{\circ} \mathrm{W}, 4$.VI.2004, R. P. Webster, silver maple swamp, margin of ver- 
nal pond in moist leaf litter on muddy soil (1 9 , RWC); Grand Lake near Scotchtown, $45.8762^{\circ} \mathrm{N}, 66.1816^{\circ} \mathrm{W}, \mathrm{R}$. P. Webster, 5.VI.2004, lake margin, under drift material (1 9 , RWC); same locality data and collector, 25.V.2006, oak and maple forest near lakeshore, in litter near vernal pond ( $1 \hat{\delta}, 1$ \% , RWC); Upper Gagetown, bog adjacent to Hwy 2, $45.8316^{\circ} \mathrm{N}, 66.2346^{\circ} \mathrm{W}, 23 . \mathrm{V} .2006$, R. P. Webster, tamarack bog, treading Carex into water (1 $\partial^{\lambda}$, RWC). Sunbury Co., Maugerville, Portobello Creek N.W.A., $45.8992^{\circ} \mathrm{N}, 66.4248^{\circ} \mathrm{W}, 5 . \mathrm{VI} .2004$, R. P. Webster, silver maple swamp, margin of small (vernal) pond, in leaf litter (1 9 , RWC); Sheffield, Portobello Creek N.W.A., $45.8952^{\circ} \mathrm{N}, 66.2728^{\circ} \mathrm{W}, 17 . \mathrm{VII} .2004$, R. P. Webster, silver maple swamp, u.v. light (1 9, RWC).

Collection and habitat data. Nearly all Tetartopeus spp. have been collected in association with wetland habitats, usually in accumulations of damp leaf litter, moss, and other debris along streams, bogs, marshes, swamps, and ponds (Watrous 1980). Watrous (1980) noted that T. capitosus (as Latrobium (Tetartopeus) punctulatum LeConte) occurred mostly in the boreal forest region but gave no specific habitat data for this species. In New Brunswick, adults of this species were found in silver maple swamps (floodplain forests), a red oak and silver maple forest, along a lake margin, and in a tamarack (Larix laricina (Du Roi) K. Koch) bog. Adults were found in leaf litter near vernal ponds, under drift material on a lake margin, and by treading Carex in a tamarack bog, and one individual was captured at an ultraviolet light.

Distribution in Canada and Alaska. AK, NT, BC, AB, SK, MB, ON, QC, NB, NS (Watrous 1980; Campbell and Davies 1991).

\section{Tetartopeus rubripennis Casey, 1905}

http://species-id.net/wiki/Tetartopeus_rubripennis

Map 10

Material examined. New Brunswick, Madawaska Co., at Green River, $47.6918^{\circ} \mathrm{N}$, $68.3202^{\circ} \mathrm{W}, 21 . \mathrm{VI} .2010$, M. Turgeon \& R. Webster, river margin among gravel on gravel bar (1 9 , RWC). Restigouche Co., Jacquet River Gorge P.N.A., $47.8197^{\circ} \mathrm{N}$, $66.0835^{\circ} \mathrm{W}, 26 . V I .2008$, R. P. Webster, margin of Jacquet River among cobblestones near water ( $1 \mathrm{O}$, RWC); same locality and collector but $47.7894^{\circ} \mathrm{N}, 66.1065^{\circ} \mathrm{W}$, 14.V.2010, river margin (Jacquet River), under drift material (1 $\delta$, RWC); same locality and collector but $47.8257^{\circ} \mathrm{N}, 66.0779^{\circ} \mathrm{W}, 24 . \mathrm{V} .2010$, partially shaded cobblestone bar near outflow of brook at Jacquet River, under cobblestones and gravel (1 9 , RWC); Kedgwick Forks, $47.9085^{\circ} \mathrm{N}, 67.9057^{\circ} \mathrm{W}, 22 . V I .2010$, R. P. Webster, river margin, gravel bar among gravel and cobblestones ( $1 \hat{\jmath}, 2$, RWC).

Collection and habitat data. Watrous (1980) reported T. rubripennis (as Lathrobium (Tetartopeus) rubripenne) primarily from thin litter in marshes at one locality. In northern New Brunswick, T. rubripennis was found along river margins among gravel 
and cobblestones or under drift material, usually near water. Adults were collected during May and June.

Distribution in Canada and Alaska. ON, QC, NB, NS (Campbell and Davies 1991). In the description of T. rubripennis, Watrous (1980) noted that the elytra are usually entirely red and rarely black with only apices reddish. Only one of the seven specimens of this species from New Brunswick had entirely reddish elytra. However, the male genitalia of the dark specimens conform to the illustration (Fig. 51) given in Watrous (1980) for T. rubripennis. There are also specimens of the dark form from Nova Scotia and Quebec in the CNC (A. Davies, personal communication).

\section{Lobrathium (Eulathrobium) grande (LeConte, 1863)}

http://species-id.net/wiki/Lobrathium_grande

Map 11

Material examined. New Brunswick, Charlotte Co., near Clark Ridge, $45.3155^{\circ} \mathrm{N}$, $67.4406^{\circ} \mathrm{W}, 27$. V.2007, R. P. Webster, beaver pond, treading vegetation (1, NBM). Queens Co., Scotchtown near Indian Point (at Grand Lake), $45.8762^{\circ} \mathrm{N}, 66.1816^{\circ} \mathrm{W}$, R. P. Webster, 5.VI.2004, lake margin, under drift material (3, RWC); W of Jemseg near Jemseg River, $45.8255^{\circ} \mathrm{N}, 66.1174^{\circ} \mathrm{W}, 1 . V I I .2008, \mathrm{R}$. P. Webster, seasonally flooded marsh, treading vegetation on margin of pool 1, NBM); Grand Lake Meadows P.N.A., $45.8227^{\circ} \mathrm{N}, 66.1209^{\circ} \mathrm{W}, 14-19 . V .2010$, R. Webster \& C. MacKay, old silver maple forest with green ash and seasonally flooded marsh, Lindgren funnel trap (1, AFC); same locality data and forest type, 5-19.VII.2011, 19.VII-5.VIII.2011, M. Roy \& V. Webster, Lindgren funnel traps (2, AFC, NBM). Sunbury Co., Maugerville, Portobello Creek N.W.A., $45.8992^{\circ}$ N, 66.4248W, 27.V.2004, 5.VI.2004, R. P. Webster, silver maple forest, margin of small (vernal) pond, in leaf litter (5, RWC); Sheffield, Portobello Creek N.W.A., 45.8952 N, 66.2728 ${ }^{\circ}$ W, 24.VI.2004, R. P. Webster, seasonally flood marsh, treading marsh vegetation (1, RWC). York Co., Douglas, near Nashwaaksis River, 45.9845N, 66.6908 W, 4.VI.2003, R. P. Webster, silver maple forest, margin of small pond in leaf litter (1, RWC); Charters Settlement, $45.8340^{\circ} \mathrm{N}$, $66.7450^{\circ} \mathrm{W}, 27 . I V .2006$, R. P. Webster, mixed forest, margin of vernal pond in moist leaves $(1$, NBM).

Collection and habitat data. Watrous (1981) reported Lobrathium grande from a variety of riparian habitats. Adults occurred in moss roots, in leaf litter and sticks at a stream margin, in litter in a North American beaver (Castor canadensis Kuhl) lodge and in leaf litter at the margin of a swamp. Larvae were described by Watrous (1981). In New Brunswick, was adults were found in silver maple swamps, seasonally flooded marshes, a mixed forest, and beaver pond margins. Adults were usually found among moist leaves along pond and vernal pond margins or by treading vegetation in marshes. One individual was captured in a Lindgren funnel trap deployed in an old silver maple swamp. Adults were captured during April, May, June, July, and August. 
Distribution in Canada and Alaska. ON, QC, NB, NS (Campbell and Davies 1991).

\section{Lobrathium (Lobrathium) collare (Erichson, 1840)}

http://species-id.net/wiki/Lobrathium_collare

Map 12

Material examined. New Brunswick, Carleton Co., Meduxnekeag Valley Nature Preserve, $46.1931^{\circ} \mathrm{N}, 67.6825^{\circ} \mathrm{W}, 31$. V.2005, M.-A. Giguère \& R. Webster, mixed forest, river margin, under drift material (1, RWC). Queens Co., Scotchtown near Indian Point (at Grand Lake), $45.8762^{\circ} \mathrm{N}, 66.1816^{\circ} \mathrm{W}, \mathrm{R}$. P. Webster, 5.VI.2004, lake margin, under drift material (1, RWC); Bayard at Nerepis River, $45.4426^{\circ} \mathrm{N}$, $66.3380^{\circ} \mathrm{W}, 30 . \mathrm{V} .2008, \mathrm{R}$. P. Webster, river margin, on sand bar in moist sand, collected by lightly splashing sand with water (1, RWC). Sunbury Co., Sheffield, Portobello Creek N.W.A., $45.8952^{\circ} \mathrm{N}, 66.2728^{\circ} \mathrm{W}, 18 . V I .2004$, R. P. Webster, silver maple forest (swamp), black light trap (1, RWC). York Co., Charters Settlement, $45.8395^{\circ} \mathrm{N}$, $66.7391^{\circ} \mathrm{W}, 26 . V I .2003$, 1.VIII.2004, 10.VI.2005, 29.VI.2005, R. P. Webster, mixed forest, u.v. light (6, RWC).

Collection and habitat data. Two adults of this species were collected along river margins from under drift material and in sand (splashing), and at an ultraviolet light in a silver maple swamp, and near a mixed forest. Adults were collected during May, June, and August.

Distribution in Canada and Alaska. MB, ON, QC, NB, NS (Campbell and Davies 1991).

\section{Subtribe Medonina Casey, 1905}

Achenomorphus corticinus (Gravenhorst, 1802)**

http://species-id.net/wiki/Achenomorphus_corticinus

Map 13

Material examined. New Brunswick, Sunbury Co., Maugerville, Portobello Creek N.W.A., $45.8992^{\circ} \mathrm{N}, 66.4248^{\circ} \mathrm{W}, 18 . \mathrm{VI} .2004$, R. P. Webster, silver maple forest (swamp), black light trap ( 2 \%, RWC). York Co., Fredericton, Odell Park, $45.9570^{\circ} \mathrm{N}$, $66.6695^{\circ} \mathrm{W}, 19 . \mathrm{VI} .2005$, R. P. Webster, compost (with) wood chips and decaying plant material $\left(2 \mathrm{O}^{\top}, 7\right.$ \&, RWC); Charters Settlement, $45.8395^{\circ} \mathrm{N}, 66.7391^{\circ} \mathrm{W}$, 17.VII.2004, 9.VII.2008, R. P. Webster, mixed forest, u.v. light (2 +, RWC); same locality and collector but, $45.8456^{\circ} \mathrm{N}, 66.7267^{\circ} \mathrm{W}, 10 . \mathrm{VI} .2010$, beaver dam, among sticks and debris near outflow area of dam (1 sex undetermined, RWC).

Collection and habitat data. In New Brunswick, A. corticinus adults were collected at ultraviolet light near a mixed forest and in a silver maple swamp. Adults were 


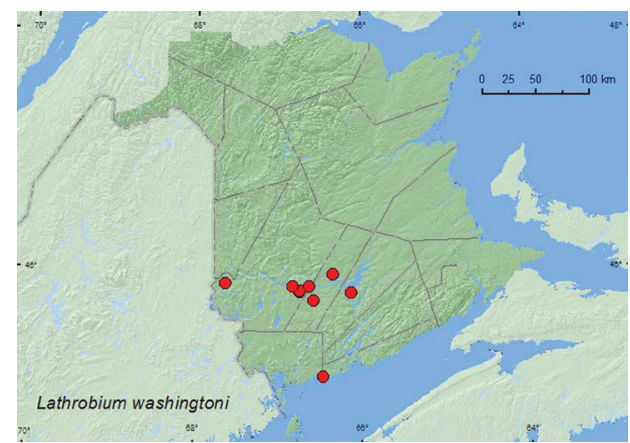

Map 7. Collection localities in New Brunswick, Canada of Lathrobium washingtoni.

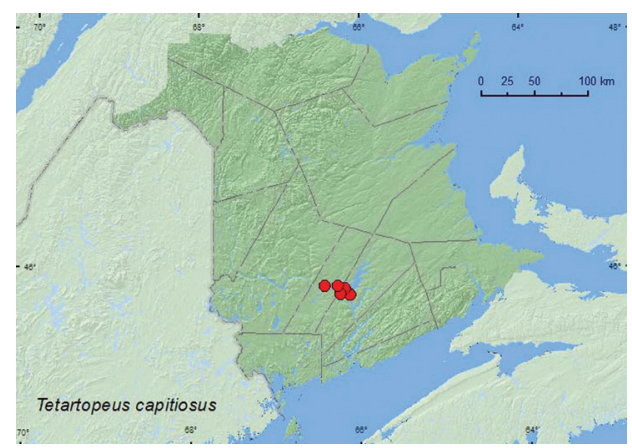

Map 9. Collection localities in New Brunswick, Canada of Tetartopeus capitosus.

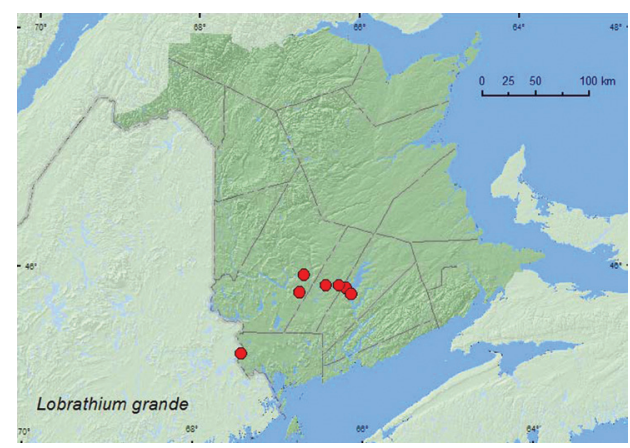

Map I I. Collection localities in New Brunswick, Canada of Lobrathium grande.

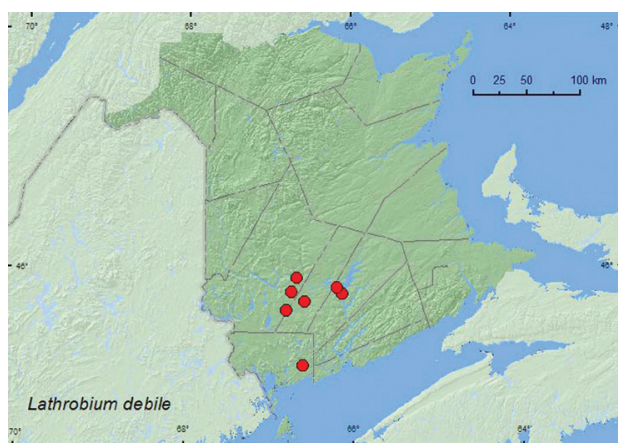

Map 8. Collection localities in New Brunswick, Canada of Lathrobium debile.

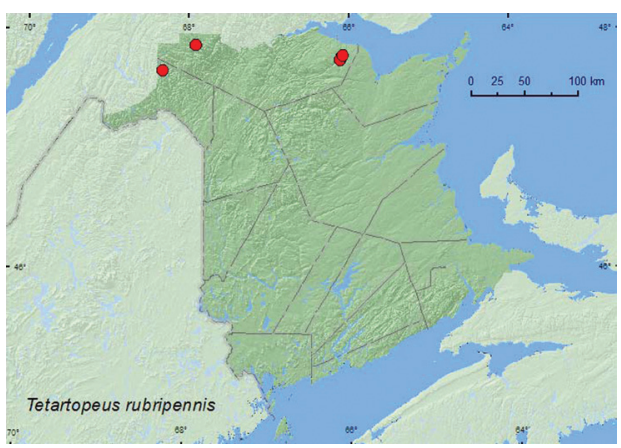

Map 10. Collection localities in New Brunswick, Canada of Tetartopeus rubripennis.

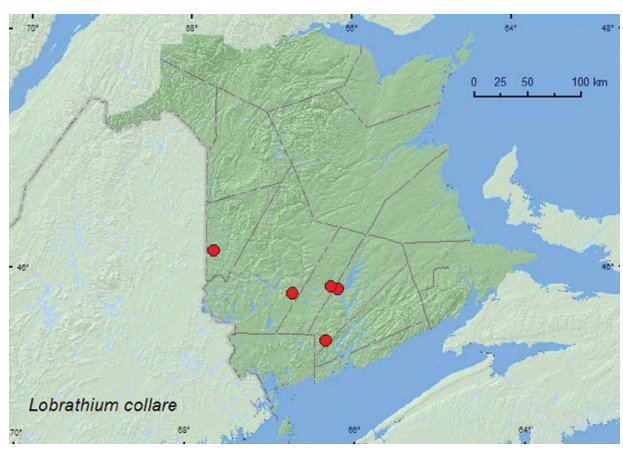

Map I2. Collection localities in New Brunswick, Canada of Lobrathium collare.

common in compost with wood chips and decaying plant material. One individual was collected from among sticks and debris near the outflow area of a beaver dam.

Distribution in Canada and Alaska. MB, ON, QC, NB (Campbell and Davies 1991). 


\section{Subtribe Stilicina Casey, 1905}

\section{Rugilus angustatus (Geoffroy, 1785)}

http://species-id.net/wiki/Rugilus_angustatus

Map 14

Material examined. New Brunswick, Carleton Co., Jackson Falls, Bell Forest, $46.2152^{\circ} \mathrm{N}, 67.7190^{\circ} \mathrm{W}, 1 . V I .2005$, M.-A. Giguère \& R. Webster, upper river margin, collected with aerial net between 16:00 and 18:00 h (2 9 , RWC); York Co., Canterbury, $45.8920^{\circ} \mathrm{N}, 67.6592^{\circ} \mathrm{W}, 8 . V I .2004$, D. Sabine \& R. Webster, hardwood forest, wood pile, under bark ( 1 \%, NBM); Charters Settlement, $45.8340^{\circ} \mathrm{N}, 66.7450^{\circ} \mathrm{W}$, 27.IV.2005, 30.IV.2005, R. P. Webster, mixed forest, in wood pile, under (loose) bark of spruce (5 $\mathrm{O}^{\lambda}, 2$ \%, RWC); Fredericton, at Saint John River, $45.9588^{\circ} \mathrm{N}, 66.6254^{\circ} \mathrm{W}$, 7.VI.2005, R. P. Webster, river margin in flood debris (1 +, NBM); Fredericton, Odell Park, $45.9570^{\circ} \mathrm{N}, 66.6695^{\circ} \mathrm{W}, 19 . \mathrm{VI} .2005$, R. P. Webster, compost (with) wood chips and decaying plant material $\left(1 \mathrm{O}^{\top}, \mathrm{NBM}\right)$; Fredericton, $45.9361^{\circ} \mathrm{N}, 66.6747^{\circ} \mathrm{W}$, 17.VIII.2009, R. P. Webster, beaver dam, outer margin under over-hanging sticks near water $(1 \hat{\jmath}, \mathrm{RWC})$.

Collection and habitat data. In the Palaearctic region, $R$. angustatus occurs under decaying organic matter along forest borders and watercourses and in meadows (Hoebeke 1995). In New Brunswick, adults of this adventive species were found along river margins, in hardwood and mixed forests, and in a beaver dam. Adults were found under loose bark in wood piles, among composted wood chips and decaying plant material, under overhanging sticks on the outer margin of a beaver dam, and in flood debris on a river margin. Two individuals were collected with an aerial net during evening flight (16:00-18:00 h) on a river margin. Adults were collected during April, June, and August.

Distribution in Canada and Alaska. ON, QC, NB, NS (Campbell and Davies 1991; Hoebeke 1995).

\section{Rugilus rufipes Germar, 1836** \\ http://species-id.net/wiki/Rugilus_rufipes \\ Map 15}

Material examined. New Brunswick, Carleton Co., Jackson Falls, Bell Forest, $46.2152^{\circ} \mathrm{N}$, $67.7190^{\circ} \mathrm{W}, 15 . \mathrm{IX} .2004, \mathrm{R}$. P. Webster, upper river margin, under litter on clay soil (2 $\mathrm{O}^{\top}$, 1 , NBM, RWC); same locality and collector but $46.2246^{\circ} \mathrm{N}, 67.7206^{\circ} \mathrm{W}, 12 . I \mathrm{~V} .2007$, upper river margin, in drift material in area without snow cover, adults very active ( $2 \mathrm{O}^{\lambda}$, 3 ㅇ, RWC); same locality but $46.2200^{\circ} \mathrm{N}, 67.7231^{\circ} \mathrm{W}, 20-26 . V .2009$, M.-A. Giguère \& R. Webster, mature hardwood forest, Lindgren funnel traps (2, AFC); Meduxnekeag River Valley Nature Preserve, $46.1907^{\circ} \mathrm{N}, 67.6740^{\circ} \mathrm{W}, 20 . V I .2006$, R. P. Webster, mixed forest, in decaying gilled mushroom, (2 ${ }^{\top}$, RWC); Jackson Falls, $46.2257^{\circ} \mathrm{N}, 67.7437^{\circ} \mathrm{W}$, 
18.VI.2010, R. P. Webster, water falls, splashing moss on rocks near fast flowing water (1, RWC). York Co., Charters Settlement, 45.8395N, 66.7391W, 23.IX.2009, R. P. Webster, mixed forest, in decaying (moldy) corncobs and cornhusks (1, RWC).

Collection and habitat data. This adventive Palaearctic species lives in both dry and wet habitats in the Palaearctic region, including meadows, fields, heaths, forests, and hilly steppe (Hoebeke 1995). Adults occurred in decaying organic matter and compost, under stones, and among leaves. In New Brunswick, adults were collected from grass litter and drift material along river margins and from decaying gilled mushrooms and decaying (moldy) corncobs and cornhusks in mixed and hardwood forests. One individual was collected from wet moss on rocks adjacent to a waterfall. Adults become active very early in the season when a deep snow cover is still present, as a number of very active adults were collected from a sun-exposed bare patch of drift material on an upper river margin on 12 April when a $60-\mathrm{cm}$ snow pack was still present. Adults were captured during April, May, June, and September.

Distribution in Canada and Alaska. ON, QC, NB, (Campbell and Davies 1991; Hoebeke 1995).

\section{Subtribe Cryptobiina Casey, 1905}

\section{Homaeotarsus (Gastrolobium) bicolor (Gravenhorst, 1802)**}

http://species-id.net/wiki/Homaeotarsus_bicolor

Map 16

Material examined. New Brunswick, Carleton Co., Belleville, Meduxnekeag River Valley Nature Preserve, $46.1944^{\circ} \mathrm{N}, 67.6832^{\circ} \mathrm{W}, 2$.VI.2008, R. P. Webster, river margin, under cobblestone in sand/gravel among scattered grasses (1, RWC).

Collection and habitat data. Homaeotarus are generally riparian and occur along river margins (Brunke et al. 2011). The single adult of $H$. bicolor from New Brunswick was collected from under a cobblestone along a river margin during early June.

Distribution in Canada and Alaska. ON, QC, NB (Campbell and Davies 1991).

Homaeotarsus (Hesperobium) cinctus (Say, 1830)

http://species-id.net/wiki/Homaeotarsus_cinctus

Map 17

Material examined. New Brunswick, Carleton Co., "Two Mile Brook Fen", $46.3619^{\circ} \mathrm{N}, 67.6730^{\circ} \mathrm{W}, 6$. V.2005, M.-A. Giguère \& R. Webster, calcareous cedar fen, open area with sedges, in sphagnum hummock (3, RWC). Charlotte Co., near New River, $45.1616^{\circ} \mathrm{N}, 66.6649^{\circ} \mathrm{W}, 7 . V I I .2006$, R. P. Webster, mixed forest in sedge marsh, treading sedges (1, NBM). Madawaska Co., Loon Lake, $236 \mathrm{~m}$ elev., 47.7839² N, $68.3943^{\circ} \mathrm{W}, 21 . \mathrm{VI} .2010$, R. P. Webster, boreal forest, small lake surrounded by sedges, 
treading sedges and grasses into water (1, NBM). Restigouche Co., Jacquet River Gorge P.N.A., $47.8207^{\circ} \mathrm{N}, 65.9955^{\circ} \mathrm{W}, 12$. VIII.2010, R. P. Webster, black spruce bog, treading vegetation (Carex \& sphagnum) (1, NBM). Saint John Co., Chance Harbour off Rt. $790,45.1374^{\circ} \mathrm{N}, 66.3633^{\circ} \mathrm{W}, 25 . V I .2010$, R. P. Webster, saturated green sphagnum mat, treading (1, NBM). York Co., Canterbury, Browns Mountain Fen, $45.8967^{\circ} \mathrm{N}, 67.6344^{\circ} \mathrm{W}, 21$. VII.2004, D. Sabine, R. Webster, \& J. Edsall, calcareous cedar fen, in moss and sphagnum among scattered sedges (1, RWC); same locality and habitat data, 2.V.2005, M.-A. Giguère \& R. Webster, open area with sedges, in sphagnum hummock (3, RWC); Charters Settlement, $45.8267^{\circ} \mathrm{N}, 66.7343^{\circ} \mathrm{W}, 14 . \mathrm{V} .2005$, 23.V.2005, R. P. Webster, margin of Carex marsh/fen, in sphagnum and leaf litter at base of tree $\left(1 \mathrm{O}^{\top}, 2\right.$ sex undetermined, RWC); Upper Brockway, $45.5684^{\circ} \mathrm{N}$, 67.0993 ${ }^{\circ} \mathrm{W}, 23 . I V .2006$, R. P. Webster, forested black spruce bog, in sphagnum (1, NBM); Magundy, $45.8491^{\circ} \mathrm{N}, 67.1573^{\circ} \mathrm{W}, 8 . V I I .2006$, R. P. Webster, kettle hole bog, treading bog margin (1, NBM).

Collection and habitat data. In New Brunswick, $H$. cinctus was found in Carex marshes, open calcareous cedar fens, a forested black spruce (Picea mariana (Mill.) B.S.P.) bog, and in a kettle hole bog with a floating bog mat. Adults were found in wet to saturated sphagnum with scattered sedges often in a floating mat, among emergent sedges and grasses, and in sphagnum hummocks. Adults were collected by treading these microhabitats. Some adults were sifted from sphagnum and leaf litter at bases of trees on a Carex marsh margin. This species was collected during April, May, June, July, and August.

Distribution in Canada and Alaska. BC, AB, ON, QC, NB, NS (Campbell and Davies 1991).

\section{Homaeotarsus (Hesperobium) cribratus (LeConte, 1863)** http://species-id.net/wiki/Homaeotarsus_cribratus Map 18}

Material examined. New Brunswick, Carleton Co., Jackson Falls, Bell Forest, $46.2208^{\circ} \mathrm{N}, 67.7211^{\circ} \mathrm{W}, 19 . I \mathrm{~V} .2005$, R. P. Webster, mature hardwood forest, in leaf litter at base of tree (2, RWC); same locality but, $46.2152^{\circ} \mathrm{N}, 67.7190^{\circ} \mathrm{W}, 11 . \mathrm{V} .2005$, M.-A. Giguère \& R. Webster, river margin, in drift material (2, RWC); same locality data and collectors, 1.VI.2005, upper river margin, collected with aerial net between 16:00 and 18:00 h (2, RWC); Belleville, Meduxnekeag River Valley Nature Preserve, $46.1888^{\circ} \mathrm{N}$, $67.6762^{\circ} \mathrm{W}, 20$. V.2005, R. P. Webster, river margin, in flood debris (2, RWC); same locality and collector but, $46.1942^{\circ} \mathrm{N}, 67.6832^{\circ} \mathrm{W}, 2$. VI.2008, river margin, under cobblestones ( $1 \mathrm{O}^{\lambda}$, RWC). York Co. Fredericton, at Saint John River, $45.9588^{\circ} \mathrm{N}, 66.6254^{\circ} \mathrm{W}$, 4.VII.2004, R. P. Webster, river margin, in drift material (mostly maple seeds) (1, RWC).

Collection and habitat data. In New Brunswick, most adults of this species were collected along river margins. Adults were collected from flood debris and drift material (maple seeds), and from under a cobblestone. Two adults were collected with an aerial 


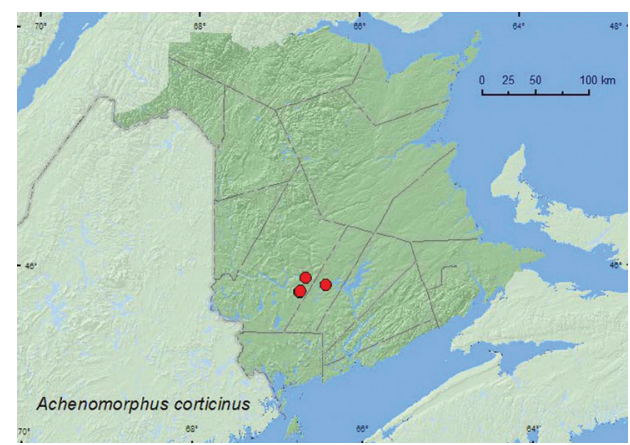

Map 13. Collection localities in New Brunswick, Canada of Achenomorphus corticinus.

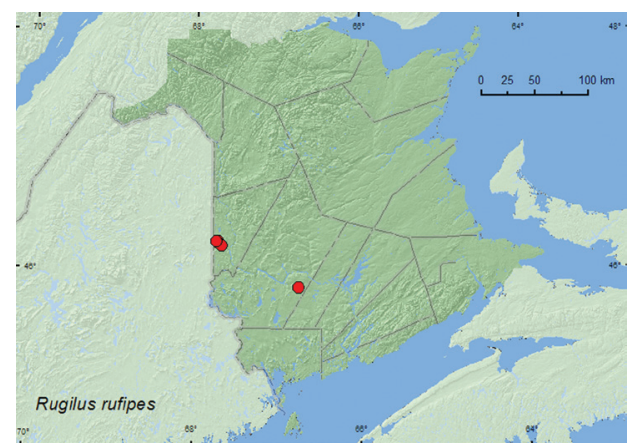

Map I5. Collection localities in New Brunswick, Canada of Rugilus rufipes.

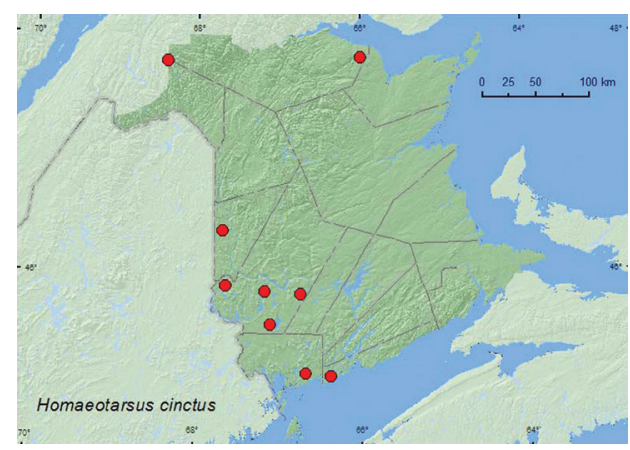

Map I7. Collection localities in New Brunswick, Canada of Homaeotarsus cinctus.

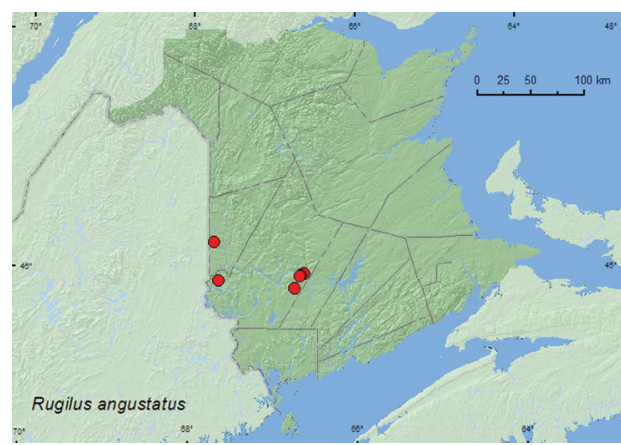

Map 14. Collection localities in New Brunswick, Canada of Rugilus angustatus.

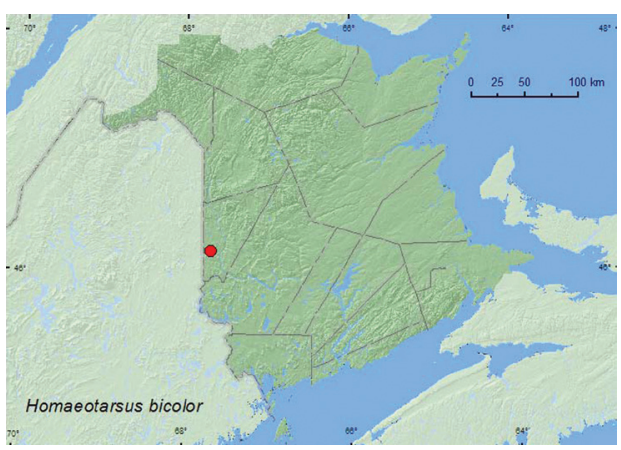

Map 16. Collection localities in New Brunswick, Canada of Homaeotarsus bicolor.

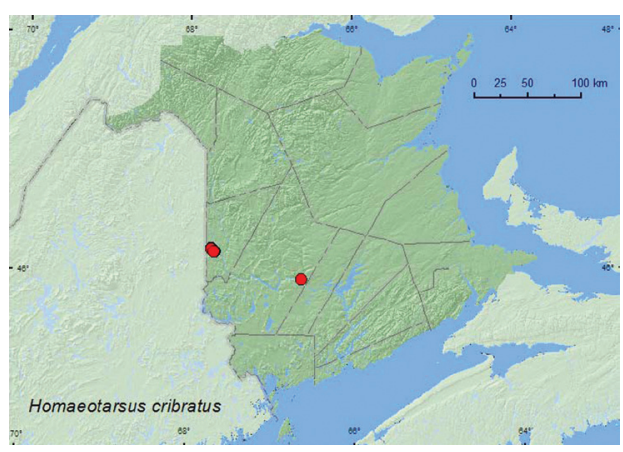

Map 18. Collection localities in New Brunswick, Canada of Homaeotarsus cribratus.

net during an evening flight (16:00-18:00 h) along a river margin, and two individuals were collected from leaf litter at the base of a tree in mature hardwood forest $(0.5 \mathrm{~km}$ from a river margin) during late April when some snow was still present. This may have been an overwintering site. Adults were collected during April, May, June, and July.

Distribution in Canada and Alaska. ON, QC, NB (Campbell and Davies 1991). 


\section{Homaeotarsus (Hesperobium) pallipes (Gravenhorst, 1802)**}

http://species-id.net/wiki/Homaeotarsus_pallipes

Map 19

Material examined. New Brunswick, York Co., Charters Settlement, $45.8456^{\circ} \mathrm{N}$, $66.7267^{\circ} \mathrm{W}, 16 . V .2010$, R. P. Webster, beaver dam, among sticks and debris near outflow area of dam (1 9 , RWC).

Collection and habitat data. The only specimen from New Brunswick was collected during May from among sticks and debris in a beaver dam near an outflow area with flowing water.

Distribution in Canada and Alaska. ON, QC, NB (Campbell and Davies 1991).

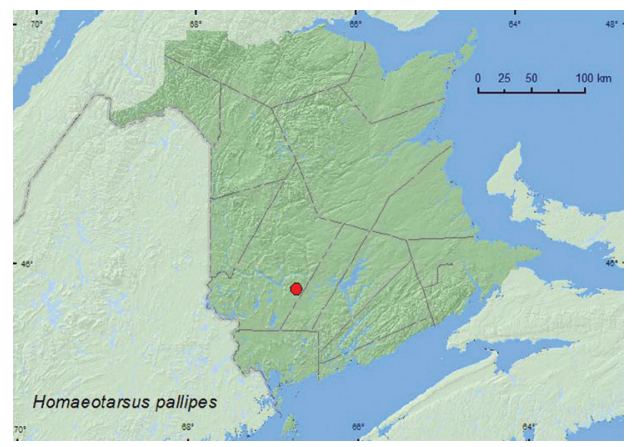

Map 19. Collection localities in New Brunswick, Canada of Homaeotarsus pallipes.

\section{Acknowledgments}

Caroline Simpson is thanked for editing this manuscript. Two anonymous reviewers are thanked for their helpful suggestions that improved this manuscript. Anthony Davies (Agriculture and Agri-Food Canada (CNC), Ottawa) is thanked for determining specimens and other invaluable assistance. Jon Sweeney (AFC) revised the first draft of this manuscript and provided very useful comments. Jon Sweeney, Nichole Brawn, Katie Burgess, Marie-Andrée Giguère, Jim Edsall, Nancy Harn, Cory Hughes, Colin MacKay, Wayne MacKay, Jessica Price, Michelle Roy, and Vincent Webster are thanked for technical assistance and collecting specimens. Natural Resources Canada, Canadian Forest Service; the Canadian Food Inspection Agency; and the USDA APHIS funded the study on early detection of invasive cerambycids, which provided the records from the specimen captured in Lindgren funnel traps. The Canadian Wildlife Service is thanked for funding insect surveys at the Portobello Creek National Wildlife Area, the New Brunswick Environmental Trust Fund and New Brunswick Wildlife Trust Fund are thanked for funding various insect surveys over the past 7 years, and the Meduxnekeag River Association is thanked for permission to sample beetles at the Meduxnekeag Valley Nature Preserve (which includes the Bell Forest). The New Brunswick Department 
of Natural Resources (Fish and Wildlife Branch) is thanked for issuing permits for sampling in the Protected Natural Areas and for providing logistical support. Survey work in the Jacquet River Gorge Protected Natural Area was organized through the New Brunswick Museum with external funding from the New Brunswick Environmental Trust Fund, Salamander Foundation, and the New Brunswick Wildlife Trust Fund.

\section{References}

Bouchard P, Bousquet Y, Davies AE, Alonso-Zarazaga MA, Lawrence JF, Lyal CHC, Newton AF, Reid CAM, Schmitt M, Ślipiński SA, Smith ABT (2011) Family-group names in Coleoptera (Insecta). ZooKeys 88: 1-972. doi: 10.3897/zookeys.88.807

Brunke A, Newton A, Klimaszewski J, Majka C, Marshall S (2011) Staphylinidae of eastern Canada and adjacent United States. Key to subfamilies: Staphylininae: tribes and subtribes, and species of Staphylinina. Canadian Journal of Arthropod Identification 12: 1-110.

Campbell JM (1973) A revision of the genus Tachinus (Coleoptera: Staphylinidae) of North and Central America. Memoirs of the Entomological Society of Canada 90: 1-137. doi: $10.4039 /$ entm $10590 \mathrm{fv}$

Campbell JM, Davies A (1991) Family Staphylinidae: rove beetles. In: Bousquet Y (Ed) Checklist of Beetles of Canada and Alaska. Agriculture Canada, Research Branch, Ottawa, Ontario, Publication 1861/E, 86-124.

Casey TL (1905) A revision of the American Paederini. Transactions of the Academy of Science of St. Louis 15: 17-248.

Casey TL (1910) Synonymic and descriptive notes on the Paederini and Pinophilini, In: Memoirs on the Coleoptera, Vol. 1. New Era, Lancaster, Pennsylvania, 184-201.

Herman LH (1965a) A revision of Orus Casey. I. Subgenus Leucorus Casey and a new subgenus (Coleoptera: Staphylinidae). The Coleopterists Bulletin 18: 112-121.

Herman LH (1965b) A revision of Orus Casey. II. Subgenera Orus, Pycnorus and Nivorus (Coleoptera: Staphylinidae). The Coleopterists Bulletin 19: 73-90.

Hoebeke RE (1995) Three Palearctic species of Rugilus Leach in North America (Coleoptera: Staphylinidae, Paederinae): redescriptions, new synonymy, and new records. Insecta Mundi 9: 69-80.

Lindgren BS (1983) A multiple funnel trap for scolytid beetles (Coleoptera). The Canadian Entomologist 115: 299-302. doi: 10.4039/Ent115299-3

Klimaszewski J, Sweeney J, Price J, Pelletier G (2005) Rove beetles (Coleoptera: Staphylinidae) in red spruce stands, eastern Canada: diversity, abundance, and descriptions of new species. The Canadian Entomologist 137: 1-48. doi: 10.4039/n03-123

Majka CG, Klimaszewski J (2008) Adventive Staphylinidae (Coleoptera) of the Maritime provinces of Canada: further contributions. ZooKeys 2: 151-174. doi: 10.3897/zookeys.2.5

Newton AF, Thayer MK, Ashe JS, Chandler DS (2000) [2001] Family 22. Staphylinidae Latreille, 1802. In: Arnett RH, Thomas MC (Eds) American Beetles. Volume 1. Archostemata, Myxophaga, Adephaga, Polyphaga. CRC Press, Boca Raton, Florida, xv + 272-418. 
Watrous LE (1980) Studies of Lathrobium (Tetrartopeus): natural history, revision, and phylogeny of Nearctic species. Systematic Entomology 5: 303-338. doi: 10.1111/j.13653113.1980.tb00418.x

Watrous LE (1981) Studies of Lathrobium (Lobrathium): Revision of the grande species group (Coleoptera: Staphylinidae). Annals of the Entomological Society of America: 74: 144-150.

Webster RP, Klimaszewski J, Pelletier G, Savard K (2009) New Staphylinidae (Coleoptera) records with new collection data from New Brunswick, Canada. I. Aleocharinae. In: Majka CG, Klimaszewski J (Eds) Biodiversity, biosystematics, and ecology of Canadian Coleoptera II. ZooKeys 22: 171-248. doi: 10.3897/zookeys.22.152

Webster RP, Smetana A, Sweeney JD, DeMerchant I (2012) New Staphylinidae (Coleoptera) records with new collection data from New Brunswick and an addition to the fauna of Quebec: Staphylininae. In: Klimaszewski J, Anderson R (Eds) Biosystematics and Ecology of Canadian Staphylinidae (Coleoptera) II. ZooKeys 186: 293-348. doi: 10.3897/ zookeys.186.2469 